\title{
MANAGEMENT SPECIALISTS IN THE KNOWLEDGE BASED SOCIETY: LIFE-LONG LEARNING ORIENTED HUMAN RESOURSE DEVELOPMENT
}

\author{
Borisas Melnikas \\ Vilnius Gediminas Technical University, Sauletekioal.11,LT-10223Vilnius-40,Lithuania, e-mail: melnikas@vv.vtu.lt
}

Received 0707 2005; accepted 06092005

\begin{abstract}
The publication presents an analysis of management specialist development problems arising in today's situation. Special attention is paid to management specialist development in the conditions of globalization, knowledge society development, European integration and the European Union enlargement.

The publication provides an in-depth analysis of management specialists development principles and practical experiences in the area of management specialist development.

The absence of well-founded general principles of management specialist development as well as special principles of business and public management specialist development remains an important research problem. The absence of integrated and individualized university studies and of the practical realization of the life-long learning principle in the area of management specialist development remains an important practical problem.

The aim of the publication - to formulate and ground the main principles of management specialist development as well as to describe an original management specialist development model based on the implementation of the idea of life long learning.

The research methodology is based on the concept of triangulation, combining the descriptive analysis, surveys and expert evaluation.

The scientific novelty, theoretical and practical results are defined by the following:

1. The following groups of principles are singled out: a) general development principles, applicable to specialists of all fields, including that of management; b) special principles of management specialist development, applicable exceptionally to management specialist development; c) specific principles of business management specialist development; d) specific principles of public management specialist development, applicable exceptionally to the development of specialists working in the public sector and public management. This model provides for combination of diverse forms of learning, university studies, independent researches, self-development and in-service training; long-term individual programmers are designed to help people acquire different qualifications and develop their competences through studies in universities and other educational institutions and through participating in practical works, workshops and seminars. Introduction of long-term individualized development programmers facilitates development of unique managerial skills and prepares every specialist for a unique position, a unique professional activity and individualized functions.

2. The management specialist development model based on the implementation of the idea of life - long learning as well as integrated and individualized university and non - university studies is described.

3. An important element of management specialist development process is development of human creativity. It also depicts specific characteristics of creativity and highlights new opportunities and possibilities for the development of the creative potential.
\end{abstract}

Keywords: management, specialist, learning, knowledge society, creativity, university studies, innovation.

\section{Introduction}

Like other Baltic States and Eastern and Central Europe, Lithuania is currently witnessing fundamental social and economic changes caused by the European Union enlargement process and growing integration within the European Union, as well as by more general processes of economic, social, cultural and political globalization, information society formation and intensive international cooperation development. These changes affect all spheres of life including that of management specialist development improvement.

In contemporary society managerial activity is gaining increasingly more significance. This is due to the fact that management quality and efficiency of managerial actions and decisions are becoming an essential and even crucial factor of progress in practically all areas of life. It is the capacity to manage that facilitates timely perception and appropriate solution of topical social, economic, technological, ecological, political, military, defense and other problems in enterprises, 
institutions and other organizations, as well as in regions and countries of various size and on the international level. Hence, improvement of managerial human resource quality, which may take the form of modernization of the management specialist development systems, can be viewed as a critically important condition for the development of contemporary society. We may claim that development of the potential of managerial human resources is an important priority of contemporary society and state.

Well aware of the importance of managerial human resources quality and its development we may raise a question - is the present quality of management specialists and their development systems good enough to meet the challenges of the fast-developing modern society? Do the management specialists have the possibilities to adapt successfully to the new conditions of globalization and information society? What is more, can they make a positive impact on further social, economic and technological development and directly programmer new advanced qualitative changes in the society?

These questions are constantly raised by both practitioners and scholars; the topicality of these questions is witnessed by the broad variety of resources of the latest publications of scientific and practical character on management, especially public management issues.

Seeking to answer the above mentioned questions we encounter a serious and complex scientific problem: modern science and practice lacks clear criteria and principles which would guide formulation of wellgrounded requirements for modern management specialist development and implementation of which would facilitate enhancement of management specialist development systems.

The fact that the criteria and principles for assessment of management specialist development systems and their enhancement measures are irrelevant to the challenges of the modern world is a topical and complex scientific problem.

Topicality of this scientific problem results from the necessity to perceive management specialist development as a system, further development of which could have a direct and positive impact on social, economic and technological progress adequate to possibilities provided by globalization, development of international cooperation and dissemination of ideas of information society. Furthermore, the modern world is witnessing a rapid formation of multicultural managerial spaces, where priority is given to global economy and international cooperation, and very intensive processes of automatization, robotization and increasing expansion of information technologies that lead to high concentration of intellectual work in managerial activity. Management specialist development systems must have the capacity to react to this situation and to manage those global processes which can be subject to managerial activity.

Complexity of this scientific problem is predetermined by the fact that recognition of a problem and search for possible solutions requires integration of many scientific fields and trends, as well as synthesis of theoretical suppositions and practical actions and decisions: enhancement of management specialist development requires a complex approach, empirical tests of various theoretical models, experiments and practical studies.

The aim of this publication is to reveal the problem areas related to modern management specialist development, especially public management specialist development and its enhancement, as well as suggest some solutions of those problems, paying special attention to those of them which could be applied directly to situations in Lithuania.

\section{Enhancement of management specialist development system as an essential prerequisite for modernization of contemporary society}

Contemporary society and its development can be characterized by some complex phenomena, embodying challenges of the 21 st century, its values and further development priorities.

Contemporary society and its development can be characterized by the following:

development of society is taking place in the conditions of globalization and increasing internationalization in all spheres of social, political, economic and cultural life;

- development of society is more and more determined by growing scientific and technological progress, prevalence of knowledge and information society models and standards, intensive processes of automatization, robotization, mechanization and increasing expansion of information technologies;

- life-style models and priority values are changing essentially to show greater individualization of each person, his activity or work place, rapidly shrinking direct interpersonal communication spaces and increasingly growing demand and facilities for communication through various technical 
systems (e.g. telecommunications, e-mail, mass media);

development of society is more and more influenced by international processes of standardization and unification taking part in the life of each individual as well as in various sectors of public life (e.g. economy, political, social and cultural life, education, health security, law enforcement), and on the level of states and world regions (that is especially well seen in the European Union).

On the grounds of the above mentioned significant phenomena we may claim that the role of management in contemporary society is growing rapidly; its quality and efficiency, management specialists' qualification, competence and capacity are becoming crucial factors of the modern society development. Hence, seeking to form a modern society, priority should be given to management specialist development and enhancement of management specialist development systems (Armstrong, M. A., 1999; Grace, A., Butler, T., 2005; Huseman, R. C., Godman, J. P., 1999; Leydesdorff, L., 2004; Steinmueller, W. E., 2002).

The importance of management specialist development system enhancement in present situation is determined by a few important conditions:

- management specialists' decisions and their performance have an increasing role in choosing new perspective directions and priorities for science and technology development;

management specialists tend to become a link between people and their society on the one hand and various technical and other systems on the other hand: management specialists' decisions and their actions have a growing impact on interaction between people and their society and biological, technical, informational and other environments, and also significantly affect our possibilities to use modern means of automatization, robotization, computerization, introduction of information technologies;

- management specialists' performance becomes a crucial factor in globalization and internationalization of economic, social, cultural, informational, scientific and technological development;

It is also noteworthy that elements of integration are inherent to the management specialists' professional activity and this integration has a twofold expression:

- management specialists' performance is always oriented to interaction among other people or organizations;

- $\quad$ an important characteristic of managerial activity is the combination of different activities which requires knowledge, skills and experience of different character.

Elements of integration, inherent to management specialists' performance, show that management specialists fulfill the function of synergetic effects formation. Realising the rapidly growing importance of formation and use of synergetic effects in the modern society development we may claim that enhancement of management specialist development as a means of increasing the potential of synergetic effects formation is becoming an essential prerequisite for modernization of the contemporary society (Currie, W., 2000; David, P. A., Foray, D., 2002; Goeransson, B., Soederberg, J., 2005; Hunt, S. D., 2000; McNally, R., 1999; Olsen, T. E., Osmundsen, P., 2003).

Awareness of the importance of management specialist development determines the necessity to identify the main problems arising in this field and to outline specific ways to design and enhance efficient management specialist development systems

There are many specific characteristics of management specialist development in various countries and under various conditions. For instance, while trying to assess management specialist development in Lithuania at the present moment much attention should be paid to the factors which are specific to the transition period of integration into the European Union.

In-depth analysis of management specialist development practice in Lithuania and other countries shows that the following groups of problems can be distinguished:

- problems related to the content of management specialist development;

- problems related to management specialist development technologies;

- problems related to the operation of institutions, enterprises and organizations involved in processes of the management specialist development;

Among the problems related to the content of management specialist development first and foremost comes inadequate integrity of various development processes; lack of integrity leads to the following:

theoretical education (providing and acquiring theoretical knowledge) is not well balanced against practical training (providing and gaining practical knowledge, also developing practical skills and competences);

- due to improper specialization of the education the knowledge and skills acquired often lack systematic character;

- the content of the education is sometimes 
irrelevant to the individual's specific needs, inclinations, abilities and values;

- $\quad$ it is not rare that education is inadequately linked to the professional prospects of the people, as well as with the latest trends in various fields of economic and social development and with progress of science and technology;

- development is quite often insufficiently oriented to the people's ability to get adjusted to the fastchanging environment and adapt their knowledge and skills to new situations, needs and requirements;

- development quite often lacks orientation to the independence and responsibility of the people and does not encourage their capability of independent decision-making;

- development is not differentiated according to needs and possibilities to develop both leaders and reliable executives;

- the content of the development is often irrelevant to the requirements which are determined by the necessity of team decision-making, team-work and tolerance of other opinions ;

- the content of the development often lacks links to the issues of concern in the fields of society development and social, economic, scientific and technological progress; besides, it fails to be oriented to the solution of these problems; the content of the development is not wellbalanced; i.e. there is no harmony in such fields as dissemination and acquisition of new knowledge, development of new skills and capacities, raising morality, responsibility and spirituality, adequate development of physical qualities and psychological and cultural orientations;

- the content of the development quite often shows inadequate orientation to openness, and that facilitates the emergence of diverse forms and tendencies of provinciality, superficiality, selfishness and lack of tolerance.

The above listed problems give a general overview of the main concerns in relation to the content of the development. It should be noted, however, that some other problems arising from the irrelevance of the development content to the needs of modern society fall under this category as well. Special attention should be drawn to those which are specific to management specialist development in the conditions of radical social, economic and technological transformations and which are posed by new challenges of modern life (Caroli, R., Atamer, T., Nunes, P., 1999; Cohendet, P., Stojak, L., 2005; Dicken, P., 1998; Ein-Dor, P., Myers, M., Raman, K.
S., 2004; Melnikas, B., 2002; Parker, B., 1998).

In the second group of problems, related to management specialist development technologies and organizational forms, emphasis should be placed on those which arise because technologies, methods and activity forms applied in the process of management specialist development are irrelevant to the requirements which correspond to the goals of the development and to its content. The main problems in this group are as follows:

- insufficient flexibility in the application of educational technologies and activity forms, which is often described as conservatism and ignorance of the availability of the latest methodological and technical aids, information technologies and advanced organizational models;

- $\quad$ processes of the development are not sufficiently oriented to the priorities of internationalization of management specialists' activity; educational technologies and organizational forms do not always conform to the needs of internationalization of the development processes;

- developmental processes often lack consistency and continuity; educational technologies and organizational forms are not sufficiently oriented to consistent succession of separate stages and continuity of the development processes throughout each person's life;

developmental processes often lack priority of innovations and continuity: the choice of educational technologies and organizational forms often shows a tendency to apply only those which have already been applied and approved previously, rather than using those which would facilitate specialists' successful performance in the future;

- developmental technologies and organizational forms lack orientation to people's activity, independence, individual responsibility for results and their active participation in choosing the technologies and forms that they find most acceptable;

By the way, the second group of problems seems to be closely related to the problems of institutions and organizations involved in management specialist development and, therefore, they have to be analyzed as one entity.

Problems related to the operation of institutions and organizations involved in management specialist development include the following:

- problems of irrational structure of the network (or 
networks) of the institutions and organizations involved in management specialist development, showing lack of partnership between the institutions and organizations, lack of clear specialization or its irrelevance to the real needs of life, society and state, and various business sectors;

inadequacy of the quality of the human resources involved in management specialist development to modern requirements (I would especially stress lack of competence by pedagogical staff and science workers; the problem is that, although the majority of the pedagogical staff and science workers satisfy the formal criteria, in terms of real competence they fail to provide up-to-date training and development);

- inadequacy of the quality of the material resources of the institutions and organizations involved in management specialist development to modern requirements, witnessed by lack of laboratory equipment, library resources, office equipment and properly equipped premises for studies and research work;

- poor financing of the institutions and organizations involved in management specialist development; funding and the criteria for funding are totally inadequate to the modern requirements for management specialist development and to the real needs (I would especially emphasize the problem of the criteria for funding: the essence of the problem is that the system of the criteria is not oriented to meet the needs of the public, state or various business sectors but to cover up the fact that the funds allocated for specialists development are often diverted to various unofficial groups seeking personal benefit);

- inefficient management of the institutions and organizations involved in management specialist development, demonstrated by the inability to use efficiently human, material, financial and other available resources, and by inability to implement the measures that would really enhance the quality of management specialist development (not just for one-time demonstration);

- lack of interaction between the institutions and organizations directly involved in management specialist development and other institutions, organizations and companies resulting in inadequate feedback from the institutions which employ specialists to the institutions which train those specialists, and vice versa.

In conclusion, it is noteworthy that the above mentioned problems include only a part of the real problems now present in the field of management specialist development. However, the above mentioned problems are considered to be the main ones and therefore their solution should be a top priority.

Taking in view many specific features of management specialist development and various possibilities to enhance the whole complex of development processes, we may claim that the main priorities in dealing with management specialist development problems include: - establishment of principles for management specialist development enhancement on the basis of systematic approach, and preparation and implementation of relevant means for realization of those principles;

- development of infrastructure of interaction between systems of education and training (educational systems) and systems of professional activities of managers (professional systems);

- development of specialists' creativity and innovative potential.

The above mentioned priorities include manifold possibilities that have to be used for the purpose of management specialist development improvement; these priorities gain special significance in the light of the European Union enlargement, because they are directly aimed at increasing efficiency of managerial activity in the context of dynamic processes of globalization and development of knowledge society (Boldrin, M., Canova, F., 2001; Currie, W., 2000; Garrett, G., Mitchell, D., 2001; Hofbauer, H., 2003).

\section{Management specialist development system and the main principles of its enhancement}

\section{1. Conception of management specialist development systems and their enhancement principles}

Seeking to improve management specialist development, systematic approach has to be adopted, which would allow to regard all developmental processes as one system. That means that management specialist development has to be perceived as a systematic phenomenon and, consequently, the measures applied have to be of systematic character.

It is therefore essential to define the concept of management specialist development system. It has to be noted that this concept may be defined in several different ways because of the variety of characteristic features and assessment criteria inherent to management specialist development, which is perceived as a whole complex of certain processes.

In view of topical problems of the contemporary society and its development priorities the 
following definition of the management specialist development system could be considered as universal: management specialist development system is totality of institutions and organizations working together in the same direction and aiming at development and enhancement of the properly qualified management specialists' potential relevant to the needs raised by growing scientific and technological progress, internationalization of economic and social development, knowledge society and globalization processes, and also by priorities of sustainable development, innovativeness, competitiveness and sustained formation of capacities to deal with topical problems.

The suggested definition implies a few important aspects of the management specialist development system:

- this system is totality of institutions and organizations working together in the same direction and in cooperation with each other;

- institutions and organizations which are part of this system are united by one common goal - to develop and further enhance the potential of properly qualified management specialists;

- this system is dynamic because the institutions and organizations involved are currently operating and their operation is directed and coordinated (directed and coordinated operation enables the system to fulfill functions of management and self-regulation);

- this system is oriented to encourage specialists' ability, on the one hand, to adjust to the environment (management specialists are developed relevantly to the needs) and, on the other hand, to have a purposeful and active impact on the environment (management specialists are developed with a view to possible future needs and they have to be able to take active part in changing economic and social situations, encouraging scientific and technological progress; they also have to be innovative, creative and competitive: all these qualities show orientation to the continuity of the development); this system is oriented to both training individuals and modernization of the society, the priority being development of high quality human resources in the conditions of globalization, knowledge society and economic-social development internationalization.

The suggested definition may be viewed as universal because it is applicable to various management specialist development systems with considerable differences. Moreover, this definition is suitable when taking about both establishment and further development and enhancement of the management specialist development systems, especially public management specialist development systems.

A systematical approach is a compulsory condition for dealing with various questions that arise in the process of management specialist development systems development. Furthermore, the systematical approach has to be based on certain principles: these principles highlight the most important requirements for management specialist development and outline priorities for management specialist development enhancement.

Priorities for management specialist development system enhancement may include very wide areas. Hence, they may be classified into the following groups:

- general principles of development of modern specialists, which are applicable to development of all specialists, including management specialists;

- $\quad$ specific principles of management specialist development, which embody specific features of management specialist development;

- principles of development of management specialists of different areas, which embody peculiarities of those areas, including the area of business and public management.

A very important condition for successful development and enhancement of management specialist development systems is the ability to take these principles into consideration and to act accordingly.

\section{2. The universal principles of the specialist development in general}

The universal principles of the specialist development are those which are applicable to the establishment, development and enhancement of development systems for specialists of all areas. These principles are considered to be universal and have to be treated as priorities when dealing with essential issues of establishment and enhancement of various specialist development systems (Armstrong, M. A., 1999; Grace, A., Butler, T., 2005).

The universal principles, applicable to all modern systems of specialist development including those for development of management specialists, enable us to realize and define the most important requirements for practical specialist development. The most important among them are the following: 
- the principle of orientation to priorities of humanism, democracy, knowledge society and openness, which means that the purpose of each development system is to promote ideals and standards of humanism, democracy, knowledge society and openness;

- the principle of competitiveness of the developmental systems and its products, which means that each developmental system is oriented to producing high quality specialists, and to the system's ability to adjust to the latest requirements which are initiated by new challenges of life and by processes of global economic, social and technological development; the principle of priorities of developmental system's functions of prevention and adaptability, which means that the developmental systems aim at developing specialists who are able to adapt themselves to new requirements and who are able to deal skillfully with new problems;

- the principle of internationalization of the specialist development, which reveals prospects of the development system expansion in the context of international cooperation;

- the principle of consistency, continuity and diversification of forms of the specialist development, which means that a specialist's development is a life-long process and that this process involves a sequence of measures increasingly varying in forms; implementation of this principle requires application of a few principles of local character and each of them can be treated as a separate principle under the category of general universal principles.

The principles of local character define those requirements for developmental systems which express dynamism of development processes and the necessity to harmonize various development technologies. These principles include:

- the principle of coordination of university education, professional training and personality development, which means that university studies, professional training for development of personal qualities and abilities are compatible in terms of content and form and they are integral parts of the single developmental process;

- $\quad$ the principle of harmonizing theoretical education and practical training, which requires balancing the acquisition of theoretical knowledge with formation of practical skills; scientific research and other practical works of planning and consulting with traditional university and nonuniversity studies;
- the principle of continued post-graduate development and requalification, which means that every specialist, having obtained an academic or professional qualification certified by a degree or diploma, continues to sustain it and to enhance it with new knowledge and skills, and also requalifies, if it is required by new and rapidly changing situations.

All the above mentioned principles in total reveal the requirements which have to be applied to modern systems of development: these principles show orientation to development systems' relevance to general tendencies and challenges of the modern society.

\section{3. Specific principles of management specialist development}

As it was previously mentioned, the universal management specialist development principles are applicable to development systems of specialists in all areas, including that of management. Additionally, management specialist development systems are guided by some specific principles, which express some specific features of management specialist development.

Specific principles of management specialist development include:

- the principle of wide erudition and a complex approach to formation of knowledge and skills, which means that management specialist development system has to be oriented to the development of wide erudition and wide-range knowledge and skills of various fields of life and at the formation of various skills and abilities for different fields of activity;

- the principle of balancing general managerial competence against skills for a specific management field, which means that management specialists have to master both management knowledge and skills of general character and those inherent to a specific field of management (as to specific management skills, priority is given to knowledge of and skills in special technological, social, economic, law fields relevant to their specialization);

- the principle of innovativeness and creativity, which means that management specialist development system has to be oriented to promoting and developing innovative and creative potential the principle of priority of morality and higher social responsibility, which means that management specialist development system seeks to 
implement high standards of morality and social responsibility;

- the principle of independent decision-making, ability to react instantly to rapidly changing situation and take appropriate measures in extreme situations, which means that management specialist development system has to be oriented to the development of independent and responsible leaders;

- the principle of development of team-work skills, tolerance and adaptability, which means that management specialist development system has to aim at development of skills necessary for work in fast-changing environment of people and professionals and for taking active and constructive part in idea generation and decision making (this principle, by the way, is also directly linked to the provision to develop leaders able to work in teams and at the same time remain independent);

- the principle of adaptation to multicultural environment, which means that management professionals have to be able to adapt to any new cultural environment and to carry out their functions successfully;

The above mentioned specific principles not only express specific features of management specialist development but also outline additional requirements for management specialist development systems. It is noteworthy that such requirements are also predetermined by the factors which express specific features inherent to management of various fields, including those of business management and public management.

Peculiarities of business management and public management, which are two separate fields of management, require to define additionally the specific principles of management specialist development which are inherent to both business management and public management: awareness of these principles facilitates development and enhancement of management specialist development systems.

\section{4. Principles of business and public management specialist development}

Business management specialist development systems are guided by universal principles, applicable to specialists of all fields, and by more specific principles, applicable to management specialists, as well as by the most specific principles, applicable to the development of business management specialists.
The three groups of principles comprise all the requirements for the development and enhancement of business management specialist development systems.

Specific principles of business management specialist development express characteristic features of business management as a specific managerial activity; the most important among them could be the following: the very nature of business management is the orientation of business to fulfillment of interests (first and foremost economic interest) of business entities.

The essence of business, as it is well known, is seeking a certain result that would bring personal gain for the businessman first of all. To assess the gain priority is given to economic categories because business in general is perceived as an activity stimulated by economic interest and aimed at economic gain. It is noteworthy that an economic result in business is achieved by developing and selling a product which has to satisfy consumers' specific needs.

On the grounds of the above said it could be claimed that fundamental features of business management are orientation to fulfillment of business entity's economic interests, on the one hand and satisfaction of consumers' needs, on the other hand.

Specific nature of business management determines requirements for business management specialist development and, at the same time, specific principles of business management specialist development. These principles include:

- the principle of development of economic pragmatism priorities, which means that business management specialists have to develop their orientation to economic results;

- the principle of development of entrepreneurship skills, priority given to abilities to expand business in the environment of democracy, humanism, openness, rule of law and civil society; this principles embodies the idea that business management specialists development has to be oriented to business development in the conditions of modern democratic, moral and humane society,

- the principle of scientific and technological progress, seek for high quality and productivity, which means that orientation to scientific and technological progress, high quality and productivity are priorities of business management specialist development.

Like business management specialists development, public management specialist development systems are 
guided by both universal and specific principles, applicable to the development of all management specialists; additionally, it is guided by principles specific only to public management specialist development.

The principles specific only to public management specialist development reflect specific nature of public management; the main specific feature of public management is to ensure that subjects of public management identify and reveal interests of citizens and residents, interests of the society and its various groups and levels and interest of the state, and act in their protection.

Public management attempts to serve the interests of individual citizens and residents, of the society and its social groups and layers, and of the state. Consequently, essential features of public management are predetermined by the necessity to identify interests of the public management subject with the interest of the public and of the state, the aim of public management being to serve the public and its every member.

Specific features of public management determine requirements for public management specialist development and specific principles of public management specialist development. The main features are as follows:

- the principle of relevant identification and evaluation of the public and state interests which means that public management specialist development has to be oriented to development of skills necessary to identify and evaluate the public and state interests and then act in their interest; it also implies that the public and state interests are of top priority to the public management specialist;

- the principle of morality, justice and lawfulness, which means that priority has to be given to the development of the ability to remain moral, just and law-abiding in any situation;

- the principle of tolerance and ability to act adequately in multicultural environments and environments of diverse opinions and interests, which means that the ability to remain tolerant to other cultures, mentalities, opinions and interests in any situation is a fundamental priority.

Implementation of the above principles is a prerequisite for formation of public management specialist development systems which are relevant to the modern needs and challenges of the period of globalization and information society development.

In conclusion it has to be said that all the above principles have to be applied thoroughly to all aspects of management specialist development enhancement; they have to be applied seeking to improve:

- the content of the development;

- forms of organization of the development processes and use of technologies;

- $\quad$ activity of institutions and organizations involved in the development processes and management of this activity;

- motivation of participants of the development processes to seek for high quality of development and self-development.

Application of all the above principles may be viewed as an important precondition for increasing human resources quality and modernization of the society.

\section{Improvement of management specialist development through the development of interaction with systems of professional activity}

4. 1. Improvement of management specialist development system by means of implementation of the idea of integrated individualized university studies and "life-long" development

An essential condition for ensuring high quality management is development of modern specialist development system and its further improvement in view of the fast-changing needs of the society. This condition gains crucial importance in the countries of Central and Eastern Europe where management quality improvement is given priority due to the changes brought about by the process of integration of those countries into the European Union and by consequential political, social and economic changes (Bateman, M., 1997; Hayo, B., Seifert, W., 2003; Hofbauer, H., 2003; Lavingne, M., 1995; Melnikas, B., Reichelt, B., 2004).

Considering the many specific characteristics of the development of Central and Eastern Europe and of management traditions in those countries, a few priorities should be specified in the field of the development and further improvement of management specialist development system. The main priorities in this group include the following:

- orientation of specialist development to high standards of humanism, democracy, civil society, wide erudition and professional competence as well as to efficiency in fulfilling managerial functions in the conditions of European integration, globalization and information society development;

- $\quad$ specialist development through integration of 
various functions: selecting and rating specialists, increasing their motivation, career planning, providing university education, training, inservice training for qualification improvement and requalification, and development of various personal qualities;

- $\quad$ orientation to permanent specialist development to ensure that in the course of the development specialists get the knowledge and skills necessary for their efficient performance in the future;

- internationalization of specialist development systems, which means that the systems have to be adjusted to the conditions of international cooperation and that management specialists have to be sufficiently qualified to fulfill managerial functions on the international level; continuity and consistency of management specialist development processes and orientation of management specialist development to solution of topical problems of political, social and economic development.

To facilitate implementation of the above priorities it is necessary to provide "life-long" integrated university education (Leydesdorff, L., 2004; Melnikas, B., 2002).

"Life-long" integrated university education means that all the tools for specialist development are integrated into one single individualized process of university studies adapted to the development of every concrete specialist. This process has to include all stages of a specialist's development during his/her career - from obtaining initial qualification to further qualification improvement. The main stages of this process include the following:

- basic university education with which the person may start their career; this stage includes obtaining traditional university degrees or a specialist's diploma in a certain field; introductory training necessary to start a career in a certain field and in a certain position; continuous education and continuous training in various forms in order to enhance and refresh specialists' knowledge and develop their new skills relevantly to the changing conditions, working environment and adequately to new requirements; at some point of such continuous training specialists may acquire additional qualifications, including traditional university degrees a specialist's diploma or other qualifications (continuous education and continuous training could lead to qualification improvement through in-service training and to obtaining new qualifications through re-training: in the course of continuous education/training every specialist, having chosen any form of individual or group studies in educational centers, institutes or universities, may accumulate a certain set of subjects which will entitle them to a paper certifying their academic, professional or other qualification);

researches and studies, conducted in diverse forms of long-lasting or periodical character, aimed at resolving problems in the specialist's field of activity and, at the same time, encouraging the specialist's improvement, enhancement of his creative and innovative potential (researches and studies are viewed as a key element of the specialist's professional career and as an important part of the specialist's self-development; involvement in researches and studies is essential in pursuit of an academic qualification, confirmed by scientific degrees and titles);

- involvement in various long-lasting and temporary activities like writing projects, providing consultations, working out strategies and implementing innovations, aimed at resolving problems in the field of the specialist's activity and allowing the specialist to develop his/her administrative skills and practical knowledge.

The idea of a single individualized process of university studies for management specialist development may be realized through various forms. For realization of this idea the potential of local and foreign institutions and organizations should be fully exploited. That means that this process may involve a great number of institutions and organizations; in such cases the organizational and administrative function should be fulfilled by the educational and training centers and institutes directly involved in specialist development (those centers and institutes may be either part of universities or totally independent). It is essential that those centers and institutes organize and administer the single individualized university education process, attracting and involving different local and foreign universities, centers of academic and applied researches as well as various professional organizations, which could make a considerable input into specialist development.

This model of specialist development has some substantial advantages:

- $\quad$ specialist development is not attached to one specific university or any other educational institution; this allows to develop specialists in multicultural environment taking in view experience of international practice, adopting methods of other countries and creating open, dynamic and innovative development systems; 
- $\quad$ it respects needs and career plans of individual specialists;

- individualized educational process is closely linked to solution of the topical practical problems arising in the field of the specialist's activity;

- $\quad$ it ensures wide cooperation of universities, other educational and non-educational institutions and organizations;

- $\quad$ it enables to develop international relations and adopt the experience of international practice; this fact is of special importance to the countries of Central and Eastern Europe as they are feeling especially strong need for the Western experience;

- it provides application of modern teaching, training and research techniques, including those for distance learning, and use of modern means of telecommunications and computers;

- education, training and scientific researches are provided and conducted without attachment to one specific university or any other institution and that develops specialists' ability to adjust quickly to a new environment and new requirements.

All the above mentioned advantages prove that the idea of "life-long" integrated university studies has excellent prospects. Therefore it could be assumed that implementation of this idea will facilitate proper operation of management specialist development systems in conformity with the standards of the $21^{\text {st }}$ century.

Implementation of this idea in the countries of Central and Eastern Europe is highly important in one more aspect: further spread of this idea allows to activate processes of integration within the European Union as well as in the whole Europe.

The idea of management specialist development system improvement through the implementation of the idea of "life-long" integrated individualized university education requires further thorough studies. These studies should be carried out on the international level and their results could be used directly for modernization of the present management specialist development systems.

\section{2. Infrastructure of interaction between educational systems and systems of professional activities}

An essential precondition for improvement of specialist development is creating and enhancing those links which are to ensure and expand interaction between educational systems and systems of pro- fessional activities. Absence of such links or their inefficient functioning is a serious obstacle for tangible improvement of specialists' development (Armstrong, M. A., 1999; Merrill, R. E., Sedgwick, H. D., 1997; Steinmueller, W. E., 2002).

Interaction of educational systems with systems of professional activities can be enhanced by various means. One of them is establishing and sustaining networks of special organizations with a prospect to integrate into them organizations whose functions include to spread specialists' knowledge and advanced experience, received in the process of the development, across various professional fields. Functions of such organizations would include:

- $\quad$ spread of advanced knowledge from educational systems to systems of professional activities: this spread of knowledge in the course of specialists' development is an important prerequisite for creating a situation when professional systems start feeling the need for the knowledge and skills that future specialists are already receiving and training, but systems of professional activities are not yet aware of;

- generalization of the advanced knowledge and experience of systems of professional activities and its spread to educational systems: it is an important prerequisite for ensuring that the advanced knowledge and experience, gained in practice, is immediately spread through educational systems and that specialists undergoing training receive and accumulate it without delay.

Such twofold functions could be fulfilled by different organizations of diverse structures and with a big variety of objectives and methods; various centers of innovations, business incubators, science and technology parks and special consulting enterprises could be typical examples of such organizations. It is noteworthy that an important precondition for efficient operation of these organizations is rational specialization of each in systems of such organizations.

Quite a promising form of interaction between educational systems and professional systems is that of centers for spread of knowledge and advanced experience and networks of such centers. Such centers could be established in cooperation of universities with various business and public sector organizations. These centers would aim at attracting university staff and university students for research and practical project designing tasks, required by various business and public sectors; at the same time it would really implement the idea of interaction between specialist development systems and professional systems. 
In conclusion of the above said it could be claimed that interaction of specialist development systems with professional systems should be viewed as an essential priority of management specialist development improvement.

\subsection{Enhancement of the creative potential as a tool for management specialist development improvement}

Modern life is highly dynamic; its characteristic feature is increasing pace and scope of changes. Rapid processes of globalization and knowledge society development, new phenomena of technical progress, including increasing expansion of information technologies, automatization, new means of telecommunications, biotechnologies and bioengineering, witness growing intensiveness of life. In these conditions development of human creative potential and its better exploitation gains extra significance: people's creativity becomes a crucial factor in accelerating progress and success.

Development of human creative potential and its better exploitation can be viewed as a major factor in accelerating progress and success, on the one hand, and a top priority of social and economic development, on the other hand. It could be claimed that development of the creative potential of individuals, groups, organizations, different social layers and of all society in general should be considered an essential precondition for advancement of modern society (Caroli, R., Atamer, T., Nunes, P., 1999; Gurrie, W., 2000; David, P. A., Foray, D., 2002; Farnsworth, K., 2005; Perraton, J., 2001; Munasinghe, M., Sunkel, O., de Miguel, C., 2001; Redding, S., Venables, A. J., 2004).

The significance of human creativity and creative potential is predetermined by the following factors:

- modern technologies facilitate rapid implementation of the most unexpected and most innovative ideas: it is not the technological capabilities that determine progress and allow to resolve acute problems, but the originality and constructiveness of ideas; that means that people's ability to develop and use properly their creative powers and their ability to generate, appreciate and support new constructive ideas becomes a crucial precondition for successful solution of various economic, social, technical, ecological, political and other problems;

- $\quad$ with growing global competition in various forms priority is more often given to qualitative changes: our creativity and development and exploitation of the creative potential enables us to successfully initiate and implement qualitative changes, adjust to them and, as a result, compete efficiently.

The necessity to develop and fully exploit human creative potential requires more thorough analysis of sources of human creativity and introduction of efficient measures for development, enhancement and better exploitation of the creative potential. That means that development of creativity and creative potential should be viewed as an important field of scientific researches; moreover, these researches should be viewed as an indispensable condition for successful dealing with topical problems of economic, social and technological development.

Creativity is an essential quality showing man's exclusive nature and his belonging to social systems.

Man's creativity, as a concept, could be defined in many ways. Specialists of different fields tend to define it rather differently; however, in the majority of cases they highlight the following indications of creativity: ability to assess critically the reality and on that basis to generate, suggest and implement constructive, innovative and unconventional solutions of topical problems (Armstrong, M. A., 1999; Melnikas, B., 2002; Grace, A., Butler, T., 2005).

The most general definition of man's creativity emphasizes man's ability to critically assess the reality, realize and identify the existing or likely to emerge problem and suggest a constructive idea for solution of this problem. Such definition of creativity places emphasis on the ability to suggest an original constructive idea: the ability to generate new constructive ideas, which allow to treat problems differently and look for new constructive solutions, is considered to be the true essence of man's creativity.

The above definition of man's creativity may be considered universal. This definition suits different fields of man's activity (artistic and technical creative work, business, politics and any other activity); it also suits to characterize creativity of individuals as well as of groups and organizations, and of the whole society in general.

The above definition reflects positive evaluation of man's creativity; in other words, insufficient creativity or inadequate rate or scope of creativity enhancement can be viewed as a problem.

The problem of human creativity enhancement can be approached from different aspects:

- $\quad$ as a lack of people's creativity; 
- as an insufficient ability to enhance human creativity;

- $\quad$ as an insufficient ability to exploit the present creativity potential and insufficient ability to develop it.

Understanding of the problem of human creativity enhancement from these aspects allows to determine the most important priorities of researches for creativity enhancement. The main priorities among them are as follows:

- researches aimed at identification of reasons of the lack of human creativity;

- researches aimed at development of people's abilities to enhance their creativity;

- researches aimed at better exploitation of the creative potential leading to more constructive solution of problems.

Researches conducted in these directions are of high significance to all fields of social, economic and technological development in all countries and regions: these researches can promote innovations and search for constructive ways to accelerate social, economic and technological advancement. It is also noteworthy, that the following two creativity enhancement fields are of the highest importance:

- enhancement of creativity in business;

- enhancement of creativity in the field of developing and applying new technologies.

These two fields of human creativity enhancement should be considered of top significance in the conditions of globalization and increasing international competition: enhancement of creativity in these two particular fields enables us to solve problems of individuals as well as of the whole society, ensure high competitiveness and overall social, economic and technological advancement.

Researches into human creativity have to be conducted taking in view specific characteristics of the society and its social and economic structures, as well as specific features of technological, economic and political development of a particular period (Bateman, M., 1997; Dicken, P., 1998; Ghose, A. K., 2004; Hayo, B., Seifert, W., 2003; Hofbauer, H., 2003; Melnikas, B., 1997, 1999, 2002).

For instance, in the conditions of the contemporary Eastern and Central European countries researches have to be conducted taking in view many characteristics predetermined by transformation processes in these countries; the most significant of them are the following:

in a very short period Eastern and Central Europe underwent radical political and economic changes and that gave a strong impulse for the change of public culture and influenced human creativity and factors that determine needs for creativity;

- Eastern and Central European countries started integration into Western structures: the integration brings essentially new life style and new conditions, opportunities and possibilities for development and manifestation of human creativity;

- Eastern and Central Europe has historically developed highly specific traditions of creativity and creative work, which currently act as a specific factor encouraging transformations and innovations.

Researches conducted in different countries should also take into consideration various specific local circumstances; the main of such circumstances are the following:

- historical conditions which determine formation of a specific ethnic and social structure of the population, various ethnic and confessional culture impact priorities, including priorities of impact on creativity;

- economic conditions which reflect specific characteristics of the structure of economy and their influence to human creativity;

- political conditions which reflect specific characteristics of a political system and influence of a political situation to human creativity;

- technological conditions which express specific technological characteristics in different fields of human activity and characterize technological environment of human creative activity.

Researches aimed at creativity enhancement might be carried out by combining different methods: special attention should be paid to various opinion polls (questionnaires and in-depth interviews) and statistical methods (which identify and statistically describe correlation between characteristics of human creativity and various creativity determining factors).

These methods could be applied to investigation of possibilities for human creativity enhancement in different social layers, paying special attention to creativity in the fields of business and development and application of new technologies.

Researches aimed at creativity enhancement are important to all countries of Eastern and Central Europe. This fact is confirmed by the results of the researches conducted in Lithuania during the last 15 years: these results are very important in facilitating human creativity enhancement and in securing further 
overall political, social, economic and technological advancement.

Results of researches aimed at human creativity enhancement could find direct application in management specialist development improvement.

\section{Conclusions}

Improvement of managerial human resources is a very important direction of modernization of contemporary society, expressing orientation to priorities of intellectualization, ability to react to increasingly more rapid changes, tolerance, adaptability and competitiveness in the conditions of new challenges. These priorities gain special significance in the situation of globalization, development of international relations, internationalization of markets and information society development.

It is especially noteworthy that the above mentioned priorities are of special importance in the countries of Eastern and Central Europe, including Lithuania and other Baltic states: having acceded to the European Union these countries will have to perform highquality modernization of the whole managerial potential in a very short time and that requires to resolve many problems arising in the field of management specialist development, especially public management specialist development.

Improvement of management specialist development requires systematic approach as well as a whole complex of measures: the measures for management specialist development improvement have to include all stages of training, academic studies and scientific researches (first and foremost - university education), also various forms of in-service training, rating, career planning and specialists' professional fields; moreover, these measures have to include both individuals' activity and processes of social and economic development in different business and public sectors, regions, as well as on the state and international levels.

Management specialist development improvement requires a relevant scientific foundation.

Management specialist development improvement has to be based on diverse principles. These principles include:

- general principles of specialist development, applicable to specialists of all fields and professions, including that of management;

- $\quad$ specific principles applicable exceptionally to management specialist development;

- exceptional principles of business management specialist development;

- $\quad$ exceptional principles of public management specialist development.

Among the general principles of specialist development, applicable to specialists of all fields and professions, the following deserve most attention:

- the principle of priority of humanism, democracy, knowledge society and openness;

- $\quad$ the principle of competitiveness;

- the principle of priority of functions of prevention and adaptability;

- the principle of internationalization of the development;

- the principle of consistency, continuity and diversity of forms of the development.

The main specific principles of management specialist development are as follows:

- the principle of wide erudition and formation of a whole complex of knowledge and skills;

- the principle of coordination of general managerial competence and specific managerial activity;

- the principle of priority of innovativeness and creativity, high morality and high social responsibility;

- the principles of independent decision making, ability to react quickly to changes, taking relevant actions in extreme situations, team-working skills, adaptability to multicultural environment.

The exceptional principles of business management specialist development and public management specialist development highlight special development orientations inherent to various fields of business and public management.

Only being aware of the above principles we can develop and modernize management specialist development systems taking in view the conditions created by globalization, knowledge society formation, the European Union enlargement and increasing European integration.

Priority in applying these principles should be given to establishment and development of management specialist development systems that are based on the implementation of the idea of integrated individualized academic studies and "life-long learning". This idea could be viewed as having especially good prospects in the countries of Eastern and Central Europe, which are seeking to establish and develop modern management specialist development systems.

Further theoretical studies and practical works for public management specialist development 
improvement should be viewed as an essential prerequisite for successful encouragement of social and economic advancement in Lithuania and other Eastern and Central European countries, as well as in the whole European Union.

\section{References}

Armstrong M. A. (1999) Handbook of Human Resource Management Practice, London, Kogan Page, 922 p.

Boldrin, M., Canova, F. (2001) "Inequality and convergence in Europe - $\mathrm{s}$ regions: reconsidering European regional policies", Economic Policy, Vol. 16, issue 32, p. 205.

Calori, R., Atamer, T., Nunes, P. (1999) The Dynamics of International Competition. London, Sage Publications, $256 \mathrm{p}$.

Cultures in Central and Eastern Europe / Ed. M. Bateman. (1997), Oxford, Boston, Butterworth - Heinemann, $238 \mathrm{p}$.

Cohendet, P., Stojak, L. (2005) "The digital divide in Europe. The economic and social issues related to "knowledge-based Europe", Futuribles: Analyse et Prospective, issue 305, p. 5-28.

Currie, W. (2000) The Global Information Society. Chichester, John Wiley, 288 p.

David, P. A., Foray, D. (2002) "An introduction to the economy of the knowledge society", International Social Science Journal, issue 171, p. 5-9.

Dicken, P. (1998) Global Shift: Transforming the World Economy. London, Sage Publications; A. Paul Chapman Publishing, 512 p.

Ein-Dor, P., Myers, M., Raman, K. S. (2004) "IT industry and the knowledge economy: A four country study", Journal of Global Information Management, Vol. 12, issue 4, p. 23-49.

Farnsworth, K. (2005) "Promoting business-centred welfare: International and European business perspectives on social policy", Journal of European Social Policy, Vol. 15 , issue 1 , p. $65-80$.

Garrett, G., Mitchell, D. (2001) "Globalization, Government, Spending and Taxation in OECD Countries", European Journal of Political Research, Vol. 39, N 3, p.

Ghose, A. K. (2004) "Global ineguality and international trade", Cambridge journal of economics, Vol. 28, issue 2, p. 229-252.

Goeransson, B., Soederberg, J. (2005) "Long waves and information technologies - On the transition towards the information society", Technovation, Vol. 25, issue 3, p. 203-211.

Grace, A., Butler, T. (2005) "Beyond knowledge management: Introducing learning management systems", Journal of Cases on Information Technology, Vol. 7, issue 1, p. 53-70.
Hayo, B., Seifert, W. (2003) "Subjective economic wellbeing in Eastern Europe", Journal of Economic Psychology, Vol. 24, issue 3, p. 329-348.

Hofbauer, H. (2003) Osterweiterung. Vom Drang nach Osten zur peripheren EU - Integration - Wien, Promedia, $240 \mathrm{~S}$.

Hunt, S. D. (2000) A General Theory of Competition: Resources, Competences, Productivity. Economic Growth-London, Sage Publications, 256 p.

Huseman, R. C., Godman, J. P. (1999) Leading with Knowledge: The Nature of Competition in 21 st. Century. London, Sage Publications, 272 p.

Lavingne, M. (1995) The Economics of Transition : From Socialist Economy to Market Economy. London, Macmillan Press, 295 p.

Leydesdorff, L. (2004), “The university - industry knowledge relationship: Analyzing patents and the science base of technologies", Journal of the American Society for Information Science and Technology, Vol. 55, issue 11, p. 991-1001.

McNally, R. (1999) The Comprehensive World Atlas Stamford, Longmeadow Press, 224 p.

Melnikas, B. (1997) "The Integrations Problems of the Baltic States: Possibilities for the Formation of a Unified Technological, Economic and Social Space." East West Scientific Cooperation. Science and Technology Policy of the Baltic States and International Cooperation. NATO ASI Series, 4, Science and Technology Policy. - Dordrecht; Boston: Kluwer Academic Publisher, Vol. 15, p. 33-51.

Melnikas, B. (1999) Probleme der Integrattion der baltischen Staaten in westliche Strukturen (Berichte des Bundesinstituts fuer ostwissenschaftliche und internationale Studien), N 40, Koeln, 1999, 42 S.

Melnikas B., Jakubavičius, A., Strazdas, R. (2000) Inovacijos: verslas, vadyba, konsultavimas. Vilnius: Lietuvos inovacijų centras, $240 \mathrm{p}$.

Melnikas, B. (2002) Transformacijos. Vilnius: Vaga, 750 p.

Melnikas, B., Reichelt, B. (2004) Wirtschaft und Mentalitaet : Tendenzen der EU-Osterweiterung. Leipzig: Leifim - Verlag, $159 \mathrm{~S}$.

Merrill, R. E., Sedgwick, H. D. (1997) The New Venture Handbook. New York, Amacom, 256 p.

Olsen, T. E., Osmundsen, P. (2003) "Spillovers and International Competition for Investments", Journal of International Economics, Vol. 59, issue 1, p. 211-238.

Parker, B. (1998) Globalisation and Business Practice: Managing Across Boundaries. London, Sage Publications, $672 \mathrm{p}$.

Perraton, J. (2001) "The global economy - myths and realities", Cambridge journal of economics, Vol. 25, p. 669-684.

Redding, S., Venables, A. J. (2004) "Economic geography and international ineguality", Journal of International Economics, Vol. 62, issue 1, p. 53-82. 
Sangmon, K. (2002) "A Longitudinal Analysis of Globalization and Regionalization in International Trade: Social Network Approach", Social Forces, Vol. 81, No 2, p. 445-471.

Steinmueller, W. E. (2002) "Knowledge - based economies and information and communication technologies", International Social Science Journal, issue 171, p. 141-154.

The Sustainability of Long - Term Growth: Socioeconomic and Ecological Perspectives / Ed. M. Munasinghe, O. Sunkel, C de Miguel, (2001). Cheltenham, Edward Elgar Publishing, 464 p. 